funded, would mark the second year in a row in which the NIH budget has failed to keep pace with inflation. An increase of \$200 million for the National Cancer Institute is actually a continuation of a programme begun this year by the US Army on breast cancer research, and an increase of \$28 million for the National Center for Human Genome Research reflects a promise made by NIH director Bernadine Healy to its incoming director, Francis Collins, to set up a laboratory on the NIH campus. The National Institute for Allergy and Infectious Diseases would receive an increase of $\$ 86$ million for AIDS research. The budgets for the rest of the institutes would be flat, with actual decreases for the heart, lung and blood, ageing, alcohol abuse, arthritis, deafness, diabetes, eye, mental health and neurology institutes.

This year, for the first time, NIH has divided the budgets of each institute into three parts that correspond to its long-awaited strategic plan. Those categories - critical health needs, critical technologies and intellectual capital - are intended to demonstrate the role that NIH plays in meeting important national goals - improving public health, creating new technologies and training the next generation of scientists. But so far that message, repeated endlessly by Healy, has not been translated into more money.

"It's a devastating proposal", says David Moore of the Association of American Medical Colleges about Clinton's 1994 budget. "We have failed dramatically in getting our message through [about the value of biomedical research] to the new administration, and I don't think that Congress is going to bail us out this year. It shows how much work we have to do on the [fiscal year] 1995 budget."

Jeffrey Mervis

\section{Britain funds taxonomy studies}

London. A year after a committee of the British House of Lords criticized the government's neglect of taxonomy (see Nature 355, 488; 1992), the Natural Environment Research Council has announced that it will spend $£ 2.5$ million (US\$3.5 million) over the next five years.

Those selected to receive the funding, chosen from a pool of 19 applicants, are the University of Glasgow, the Imperial College of Science, Technology and Medicine and the University of Reading. Each will receive funding for two research fellowships, postgraduate training and research carried out with local museums.

Council officials point out that the study of taxonomy has been stimulated by recent developments in genetics and molecular biology. Its importance has been highlighted by debates on biodiversity.

David Dickson

\title{
Britain to help coal centre develop cleaner technologies
}

London. The British government is to provide an extra $£ 4$ million (US\$6 million) a year for the next three years to support research into cleaner and more efficient methods of burning coal. The new money was announced last week by the Department of Trade and Industry (DTI) as part of a White Paper (policy document) on energy policy that proposes closure of as many as 30 coal mines in preparation for the privatization of

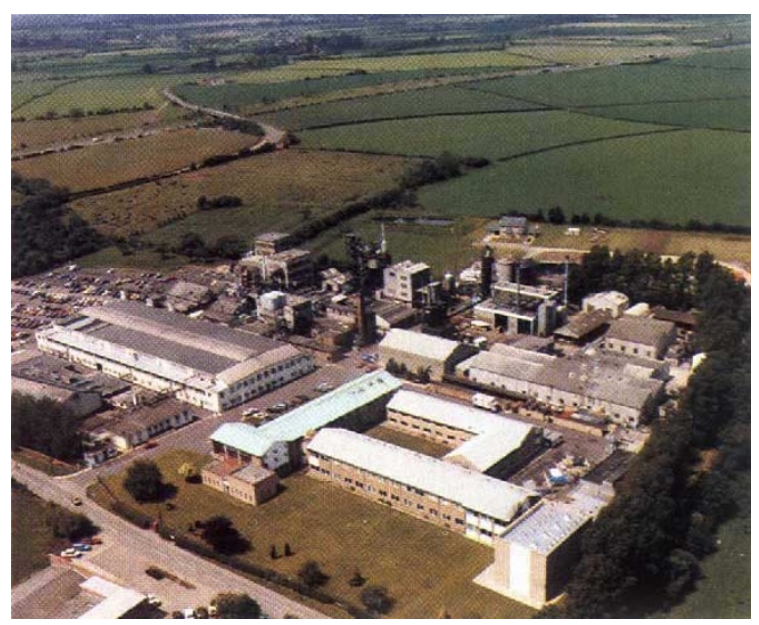

Grant staves off closure for CRE.

the coal industry. Much of it will be used to support development of the so-called 'topping cycle', a technique for burning coal pioneered in Britain that combines fluidized bed combustion and gasification techniques.

The extra funding has lifted a cloud over the future of the Coal Research Establishment (CRE) at Stoke Orchard in Gloucestershire. CRE will become an independent research centre when its parent body, British Coal Corporation, is privatized later this year. Without the support of DTI during the transition, the research centre - already suffering from low morale because of funding cuts in recent years - would have faced redundancies among scientific staff and possibly closure. But the extra money is being seen as "too little, too late" by those who believe that Britain has lost out to the United States, Japan and Germany in a race to produce environmentally acceptable coalburning technology in the next century.

Researchers at CRE have been at the forefront of efforts to develop various advanced clean-coal burning techniques. One is fluidized bed combustion, in which a stream of air from the bottom of a combustion chamber 'fluidizes' a mixture of coal and crushed limestone. A second is the gasification of coal by using steam and either oxygen or air.
However, in contrast to other coal-producing countries, Britain has been reluctant to provide public funds for plants to demonstrate the economic feasibility of its techniques. Spain has recently agreed to cover 60 per cent of the costs of a new demonstration plant using integrated gasification combined cycle (IGCC) technology largely developed in Germany, and several IGCC plants are planned in the United States with $\$ 2$ billion over several years from the Department of Energy's Clean Coal Technology Programme.

The White Paper reinforces Britain's stance by advising against a request from industry that the government provide as much as $£ 200$ million for a $300 \mathrm{MW}$ demonstration gasification plant. Such a public investment "would not be justified" at present, it concludes, adding that "international suppliers" can provide the technology when and if it is needed.

The decision to provide extra money for research and development into the topping cycle follows a report from a working party of industrialists and academics to the DTI that said the cycle offers major advantages over most competing systems in generating efficiency. But it also said that both the overall system and its components needed further development before they could be offered commercially.

In response, the government has now agreed that an industry-led consortium should take responsibility for the toppingcycle programme now carried out by British Coal and that it, together with British Coal and the European Commission, will continue to fund research into component development at the CRE.

But the government's announcement has done little to allay fears that the privatization of the coal industry will lead to a major reduction in funding. Critics point out, for example, that the successor companies to the Central Electricity Generating Board, privatized in the 1980 s, have reduced spending on research by half.

Government officials claim that the new money is designed to prevent this from happening. But others remain unconvinced and point out that the DTI's clean-coal research budget of less than $£ 5$ million pales next to the $\$ 600$ million spent last year in the United States in 1992 and is only one-tenth that of Germany.

David Dickson 